\title{
Intraspecies Genetic Relatedness among Strains of Acholeplasma laidlawii and of Acholeplasma axanthum by Nucleic Acid Hybridization
}

\author{
By E. B. STEPHENS, ${ }^{1}$ G. S. AULAKH, ${ }^{2}$ D. L. ROSE, ${ }^{3}$ J. G. TULLY ${ }^{3}$ and \\ M. F. BARILE ${ }^{1 *}$ \\ ${ }^{1}$ Mycoplasma Branch, Bureau of Biologics, Food and Drug Administration, Bethesda, \\ Maryland 20205, U.S.A. \\ ${ }^{2}$ Laboratory of Oral Medicine, National Institute of Dental Research, National Institute of \\ Health, Bethesda, Maryland 20205, U.S.A. \\ ${ }^{3}$ Mycoplasma Section, Laboratory of Molecular Microbiology, National Institute of Allergy and \\ Infectious Diseases, Frederick, Maryland 21701, U.S.A.
}

(Received 1 September 1982; revised 21 October 1982)

\begin{abstract}
This study compares the intraspecies genetic relatedness among strains of two established species of Acholeplasma. Radiolabelled DNA probes were prepared from three strains of Acholeplasma laidlawii and two strains of Acholeplasma axanthum, by using the nick translation method. The labelled DNA probes of these two strains were hybridized to an excess of unlabelled DNA from 12 strains of Acholeplasma laidlawii and from six strains of Acholeplasma axanthum, respectively. Nucleic acid hybridization analyses showed a wide variation among strains within each of the two established species, ranging from 48 to $100 \%$ homology. The results demonstrate that strains isolated from diverse hosts and habitats within a given species of Acholeplasma exhibit extensive genotypic variations.
\end{abstract}

\section{INTRODUCTION}

The acholeplasmas are a group of cell wall free prokaryotes distinguished from other members of the Mollicutes by their ability to grow in artificial medium without the addition of animal serum, cholesterol or sterols. With the possible exception of Mycoplasma arginini (Orning et al., 1978), most Mycoplasma species have a restricted host range. However, the acholeplasmas have been found widely distributed in nature, having been recovered from a variety of animals including birds, rodents, cats, swine, sheep, cattle, horses, goats and primates (Tully, 1979) and from contaminated cell cultures (Barile, 1979). In addition, acholeplasmas have been isolated from soil (Seiffert, 1937), plants and flowers (Daniels \& Meddins, 1972; Eden-Green, 1977, 1978; Eden-Green \& Tully, 1979; Kleinhempel et al., 1972; McCoy et al., 1980; Whitcomb et al., 1982) and vegetables (Somerson et al., 1982).

The current classification scheme for acholeplasmas now recognizes eight distinct species. Until recently, differentiation of each species was based on conventional serological and a limited number of biochemical tests (26). However, recent findings (Aulakh et al., 1983) have demonstrated that the eight species of Acholeplasma can be differentiated readily by nucleic acid hybridization analysis, and that these techniques can be used to examine candidate species of Acholeplasma (Aulakh et al., 1979; Rose et al., 1980; Stephens et al., 1981). Most of the strains examined in these studies were isolated from animal tissues. In order to determine genetic relatedness among strains within a given species and isolated from diverse plant and animal tissues, a comparative study was undertaken to examine a selected series of Acholeplasma axanthum and Acholeplasma laidlawii strains. This report presents the results of this study. 
Table 1. Strains of Acholeplasma laidlawii and Acholeplasma axanthum used in the study

Species and

$\begin{array}{cl}\text { strain of acholeplasma } & \text { Isolated from: } \\ \text { Acholeplasma laidlawii } & \\ \text { MIST } & \text { Compost } \\ \text { ALGEN } & \text { Soil } \\ \text { L } & \text { Soil } \\ \text { PG-9 } & \text { Sewage } \\ \text { PG-10(B-15) } & \text { Bovine, urogenital } \\ \text { J-18S } & \text { Bovine, urogenital } \\ 643 N & \text { Bovine, nasal } \\ \text { PG-5 } & \text { Rat lung } \\ \text { STR } & \text { Rat } \\ \text { H3-10 } & \text { Chicken, sinus } \\ \text { KHS } & \text { Goat } \\ \text { OR } & \text { Human, oral } \\ \text { Acholeplasma axanthum } & \\ \text { S-743 } & \text { Cell culture } \\ \text { Swine D1 } & \text { Swine } \\ \text { H86N } & \text { Bovine, nasal } \\ 1190 & \text { Sewage, lagoon } \\ \text { J248 } & \text { Coconut palm } \\ 501 & \text { Broccoli } \\ \text { Mycoplasma capricolum } & \\ \text { Calif. kid } & \text { Goat (kid) } \\ \text { Avian DNA } & \text { Duck liver }\end{array}$

Isolated by:

G. Seiffert

G. Seiffert

G. Seiffert

P. P. Laidlaw

D. G. ff. Edward

N. O. Olson

N. O. Olson

E. Kleineberger

L. Dienes

H. Alder

M. Shifrine

S. Razin

C. Friend

D. Schimmel

N. O. Olson

R. Ross

S. Eden-Green

N. Somerson

M. Tourtellotte

Prepared by one of us (G.A.)
Received from:

E. A. Freundt

E. A. Freundt

E. A. Freundt

D. G. ff. Edward

D. G. ff. Edward

D. G. ff. Edward

D. G. ff. Edward

D. G. ff. Edward

R. Lemcke

H. Adler

P. F. Smith

S. Razin

J. G. Tully

L. Stipkovits

J. G. Tully

R. Ross

J. G. Tully

ATCC 27343

\section{METHODS}

Organisms employed and cultivation techniques. The origin of the Acholeplasma species and the strains used in this study are listed in Table 1. Each strain was purified by the filtration cloning procedure as described previously (Subcommittee on the Taxonomy of Mollicutes, 1979). All acholeplasmas were grown in 41 quantities of $1 \%(w / v)$ bovine serum fraction broth medium as described elsewhere (Aulakh et al, 1979). Organisms were grown at $37^{\circ} \mathrm{C}$ for $24 \mathrm{~h}$ and collected by centrifugation $\left(16000 \mathrm{~g}\right.$ for $1 \mathrm{~h}$ in GSA rotor, Sorvall) at $4{ }^{\circ} \mathrm{C}$. The acholeplasma cell pellets were resuspended in $50 \mathrm{ml}$ Hanks' balanced salt solution and centrifuged at $27000 \mathrm{~g}$ for $30 \mathrm{~min}$ in an SS-34 rotor (Sorvall) at $4^{\circ} \mathrm{C}$. The pellets were immediately used for the purification of cell DNA. Mycoplasma capricolum (ATCC 27343) was used as a negative control organism in the hybridization studies. Avian (duck) DNA was also used as a control.

DNA purification. The pellet from each strain was lysed in a solution containing $8 \mathrm{M}$-urea, $1 \% \mathrm{SDS}, 1 \mathrm{M}-$ $\mathrm{NaClO}_{4}, 1 \mathrm{~mm}$-EDTA and $0 \cdot 24 \mathrm{M}-\mathrm{NaH}_{2} \mathrm{PO}_{4} / \mathrm{Na}_{2} \mathrm{PO}_{4}$ (PB). The DNA was purified using the hydroxyapatite batch elution method as described elsewhere (Aulakh et al., 1979; Britten et al., 1968, 1974). The purified DNA was pelleted in a Ti 60 rotor at 40000 r.p.m. for $18 \mathrm{~h}$ at $20^{\circ} \mathrm{C}$. The pellet was resuspended in TNE buffer $(0 \cdot 01 \mathrm{M}-$ Tris, pH 7.8, 0.1 M-NaCl, 0.001 M-EDTA) and stored at $4{ }^{\circ} \mathrm{C}$.

$\left[{ }^{3} \mathrm{H}\right] \mathrm{DNA}$ probe synthesis. Purified native DNA was labelled in vitro with all four labelled nucleotide triphosphates by using the nick-translation method (Kelly et al., 1970; Maniatis et al., 1975) and processed for hybridization as previously described (Aulakh et al., 1979, 1983; Britten et al., 1974). The specific activity of the $\left[{ }^{3} \mathrm{H}\right]$ DNA probes was approximately $1.5-2.0 \times 10^{7}$ c.p.m. $\mu \mathrm{g}^{-1}$.

Nucleic acid hybridization procedure. The hybridization procedures used were the same as those described previously (Aulakh \& Gallo, 1977; Aulakh et al., 1979, 1983; Stephens et al., 1981). The hybridization mixture contained $1 \mathrm{mg}$ of unlabelled sheared DNA ml ${ }^{-1}, 150000$ c.p.m. $\left[{ }^{3} \mathrm{H}\right] \mathrm{DNA}$ probe $\mathrm{ml}^{-1}$ and final concentrations of $0.4 \% 0.001 \mathrm{M}$ and $0.48 \mathrm{M}$ SDS, EDTA and PB, respectively. Reaction mixtures were denatured at $105^{\circ} \mathrm{C}$ for $5 \mathrm{~min}$ and incubated at $65^{\circ} \mathrm{C}$ overnight to a $C_{0} t$ value of $>300$ (Britten et al., 1974). Hybridized DNA was separated from single stranded DNA using a hydroxyapatite column equilibrated at $60{ }^{\circ} \mathrm{C}$ with $0 \cdot 12 \mathrm{M}-\mathrm{PB}$ containing $0 \cdot 2 \%$ SDS. Radioactive material not adsorbing to the hydroxyapatite column was considered to be single stranded DNA. The hybridized double stranded DNA was then eluted from the column with $0.48 \mathrm{M}-\mathrm{PB}$ containing $0.2 \%$ SDS.

Thermal elution midpoint $\left(t_{\mathrm{c}} 50\right)$ determinations. Thermal elution midpoints $\left(t_{\mathrm{e}} 50\right)$ were performed by preparing hydroxyapatite columns as described above. The hybridized DNA was adsorbed on to the column at $60^{\circ} \mathrm{C}$ and washed thoroughly with $0.12 \mathrm{M}-\mathrm{PB}$ containing $0.2 \% \mathrm{SDS}$ at $4{ }^{\circ} \mathrm{C}$ increments up to $100{ }^{\circ} \mathrm{C}$. All measurements of 
radioactivity were performed by adding $12 \mathrm{ml}$ Aquasol to $4 \mathrm{ml}$ of eluate and counting in a Packard Tricarb liquid scintillation counter.

Serological tests. All of the $A$. laidlawii strains had previously been shown to be related to the type strain PG-8 of this organism by growth inhibition (Clyde, 1964; Orning et al., 1978) and immunofluorescence (DelGiudice et al., 1967) serological techniques (Tully 1973; Tully \& Razin, 1968). Several of the A. axanthum strains had also been documented previously as being serologically related to the type strain S743 of this species (Tully 1973). Those not included and representing more recent isolates, were identified by growth inhibition and immunofluorescence tests with antiserum prepared to the H86N strain of $A$. axanthum, using procedures described earlier (Tully 1973; Tully \& Razin, 1968).

\section{RESULTS}

\section{Characterization of $\left[{ }^{3} H\right] D N A$ probes}

The $\left[{ }^{3} \mathrm{H}\right]$ DNA probes prepared to the PG-9, L, and MIST strains of Acholeplasma laidlawii hybridized $82.3,91.9$ and $82.0 \%$ to their homologous DNA, respectively. Similarly, the [ ${ }^{3} \mathrm{H}$ ]DNA probes derived from the S-743 and Swine D1 strains of $A$. axanthum hybridized $78.9 \%$ and $86.8 \%$ to their homologous DNA. The value obtained with homologous DNA was normalized to $100 \%$ for comparison purposes. These five $\left[{ }^{3} \mathrm{H}\right] \mathrm{DNA}$ probes did not hybridize to the unrelated DNA derived from $M$. capricolum and a background sticking between $1 \cdot 1$ and $2.9 \%$ was observed with the negative control avian (duck) DNA to hydroxyapatite columns. These results demonstrate the specificity of the probes used in this study (Tables 2 and 3).

\section{Nucleic acid homology tests with A. laidlawii}

The results of the hybridization with $\left[{ }^{3} \mathrm{H}\right] \mathrm{DNA}$ probes derived from the PG-9, L, and MIST strains of $A$. laidlawii are presented in Table 2 . A wide variation of hybridization values were seen among the various strains of $A$. laidlawii used in this study. The hybridization values for ${ }^{3} \mathrm{H}-$ MIST, ${ }^{3} \mathrm{H}-\mathrm{L}$ and ${ }^{3} \mathrm{H}-\mathrm{PG}-9$ DNA probes ranged from 63 to $93 \%$ for the 12 strains examined. Thermal elution midpoints $\left(t_{\mathrm{e}} 50\right)$ were determined for most of the homoduplexes and heteroduplexes. The $t_{\mathrm{e}} 50$ values for the three homoduplexes ranged from 82.5 to $84 \cdot 1{ }^{\circ} \mathrm{C}$ and the values for the heteroduplexes ranged from 77.6 to $83.5^{\circ} \mathrm{C}$ when tested against the two DNA probes.

\section{Nucleic acid homology tests with A. axanthum}

The results of hybridization using two $\left[{ }^{3} \mathrm{H}\right] \mathrm{DN}$ A probes of $A$. axanthum are presented in Table 3. As seen with $A$. laidlawii, $A$. axanthum also demonstrated a wide range of nucleotide diversity among the six strains used in the study, and ranged from 48.3 to $81.7 \%$ homology when tested against the strain S743 and Swine D1 [ $\left.{ }^{3} \mathrm{H}\right] \mathrm{DNA}$ probes. The $t_{\mathrm{e}} 50$ values for the two homoduplexes of the S743 and Swine D1 probes were 82.0 and $81.0^{\circ} \mathrm{C}$, respectively (Table 3). The $t_{\mathrm{e}} 50$ values of heteroduplexes with these two probes ranged from 76.0 to $80.0^{\circ} \mathrm{C}$ among the six strains examined.

\section{DISCUSSION}

We have attempted to establish here the genetic interrelationships among a number of strains isolated from diverse sources and previously identified either as A. laidlawii or A. axanthum by a number of conventional biochemical and serological tests (Tully \& Razin, 1969). We have shown previously that nucleic acid hybridization can provide a critical indicator in determining the genetic interrelationship among recognized species of Acholeplasma (Aulakh et al., 1979, 1983; Stephens et al., 1981) and Mycoplasma pneumoniae (Chandler et al., 1982). Studies on the genetic relatedness among the eight established species of Acholeplasma showed that there was very little homology among the Acholeplasma species (generally less than $10 \%$ ) although a cluster of $A$. laidlawii, A. granularum, A. oculi and A. hippikon type strains showed homologies of from 10 to $20 \%$. Prototype strains of $A$. laidlawii and $A$. granularum showed the most relatedness and hybridized at the level of $20 \%$. Thus, the distinctions observed among species of Acholeplasma 
Table 2. Degree of DNA-DNA hybridization using $\left[{ }^{3} \mathrm{H}\right] D N A$ probes derived from $A$. laidlawii strains $L$ and MIST with excess unlabelled DNA from other $A$. laidlawii strains

Percentage hybridization of

$\left[{ }^{3} \mathrm{H}\right] \mathrm{DN}$ A probe to $A$. laidlawii strains*

\begin{tabular}{llcc} 
Strain & \multicolumn{1}{c}{ Lg-9 } & MIST \\
MIST & $68 \cdot 4(83 \cdot 1)$ & $82 \cdot 7(90 \cdot 0)[83 \cdot 5]$ & $82 \cdot 0(100)[83 \cdot 2]$ \\
ALGEN & $58 \cdot 1(70 \cdot 6)$ & $68 \cdot 9(75 \cdot 0)[81 \cdot 0]$ & $65 \cdot 2(79 \cdot 5)[82 \cdot 0]$ \\
L & $64 \cdot 0(77 \cdot 8)$ & $91 \cdot 9(100)[84 \cdot 1]$ & $76 \cdot 2(92 \cdot 9)[82 \cdot 0]$ \\
PG-9 & $82 \cdot 3(100)[82 \cdot 5]$ & $72 \cdot 0(78 \cdot 0)[79 \cdot 5]$ & $68 \cdot 4(83 \cdot 0)[80 \cdot 0]$ \\
PG-10 & $59 \cdot 1(71 \cdot 8)$ & $73 \cdot 2(80 \cdot 0)[81 \cdot 0]$ & $70 \cdot 4(85 \cdot 8)[81 \cdot 5]$ \\
J18S & $65 \cdot 1(79 \cdot 1)$ & $68 \cdot 4(74 \cdot 4)[79 \cdot 0]$ & $64 \cdot 7(78 \cdot 9)[81 \cdot 0]$ \\
643N & $73 \cdot 1(88 \cdot 9)$ & $74 \cdot 4(81 \cdot 0)[80 \cdot 0]$ & $70 \cdot 4(85 \cdot 8)[79 \cdot 5]$ \\
PG-5 & $71 \cdot 7(87 \cdot 1)$ & $63 \cdot 8(69 \cdot 5)[78 \cdot 5]$ & $61 \cdot 1(74 \cdot 5)[77 \cdot 6]$ \\
STR & $58 \cdot 7(71 \cdot 3)$ & $60 \cdot 3(66 \cdot 7)[78 \cdot 0]$ & $51 \cdot 6(62 \cdot 9)[78 \cdot 4]$ \\
H3-10 & $65 \cdot 1(79 \cdot 1)$ & $55 \cdot 5(64 \cdot 5)[78 \cdot 0]$ & $57 \cdot 4(70 \cdot 0)[78 \cdot 0]$ \\
KHS & $68 \cdot 8(83 \cdot 6)$ & $62 \cdot 0(67 \cdot 4)[78 \cdot 3]$ & $59 \cdot 7(72 \cdot 8)[78 \cdot 4]$ \\
OR & $71 \cdot 8(87 \cdot 2)$ & $61 \cdot 6(67 \cdot 0)[78 \cdot 0]$ & $56 \cdot 8(69 \cdot 2)[78 \cdot 4]$ \\
$M$. capricolum & $2 \cdot 0$ & $2 \cdot 1$ & $2 \cdot 5$ \\
Duck DNA & $1 \cdot 2$ & $1 \cdot 3$ & 1.9
\end{tabular}

* Each value represents the average from two separate experiments. Values from each experiment did not differ by more than $4 \%$. The values in parentheses represent normalized valued; results for homologous DNA are shown in italic. The figures in square brackets show the thermal elution midpoint of the DNA-DNA duplexes.

Table 3. Degree of DNA-DNA hybridization using $\left[{ }^{3} H\right] D N A$ probes derived from A. axanthum strains $S 743$ and Swine D1 with excess unlabelled DNA from other A. axanthum strains

\begin{tabular}{|c|c|c|}
\hline \multirow[b]{2}{*}{ Strain } & \multicolumn{2}{|c|}{$\begin{array}{c}\text { Percentage hybridization of } \\
{\left[{ }^{3} \mathrm{H}\right] \text { DNA probe* }}\end{array}$} \\
\hline & S743 & Swine D1 \\
\hline S743 & $78.9(100)[82.0]$ & $52.5(60.8)[76.0]$ \\
\hline Swine Dl & $48.0(60.8)[76.5]$ & $86.8(100) \quad[81.0]$ \\
\hline $\mathrm{H} 86 \mathrm{~N}$ & $55 \cdot 3(70 \cdot 1)[78 \cdot 3]$ & $57.9(66.7)[77.5]$ \\
\hline 1190 & $41.8(52.9)[76.7]$ & $71 \cdot 0(81 \cdot 7)[80 \cdot 0]$ \\
\hline $\mathrm{J} 248$ & $51.3(65.0)[77.0]$ & $61 \cdot 8(71 \cdot 2)[76 \cdot 5]$ \\
\hline 501 & $41.5(52.5)[77 \cdot 0]$ & $42.0(48.3)[76.0]$ \\
\hline M. capricolum & $2 \cdot 1$ & 1.8 \\
\hline Duck DNA & $2 \cdot 9$ & $1 \cdot 1$ \\
\hline
\end{tabular}

\footnotetext{
* Each value represents the average from two separate experiments. Values from each experiment did not differ by more than $4 \%$. The values in parentheses represent normalized values; results for homologous DNA are shown in italic. The figures in square brackets show the thermal elution midpoint of the DNA-DNA duplexes.
}

attained by conventional biochemical and serological tests correlated extremely well with data obtained by nucleic acid hybridization (Aulakh et al., 1983). The availability of strains of $\boldsymbol{A}$. axanthum and $\boldsymbol{A}$. laidlawii derived from a number of diverse origins (i.e. various mammalian hosts, plants, soil, compost, sewage) provided an opportunity to study the genetic relatedness among these various strains by nucleic acid hybridization.

The results presented indicate that strains of $A$. axanthum and $A$. laidlawii (classified by serologic and biochemical procedures) showed a considerable amount of variation in nucleic acid sequence homology. The DNA probe of the Swine D1 strain of $A$. axanthum hybridized $86.8 \%$ to its homologous DNA and from $42.0 \%$ to $71.0 \%$ with DNA from five other strains of $A$. axanthum. The maximum amount of homology was observed between the Swine DI probe and strain 1190 DNA. The close relatedness between these two strains was also reflected in the $t_{\mathrm{e}} 50$ value for the heteroduplex which was only $1{ }^{\circ} \mathrm{C}$ lower than the Swine D1 homoduplexes and equivalent to only $1.5 \%$ mismatching in base pairing (Laird et al., 1969). Larger differences (4 to $5{ }^{\circ} \mathrm{C}$ ) in $t_{\mathrm{e}} 50$ were observed for the heteroduplexes of $A$. axanthum strains isolated from different 
hosts (bovine, cell culture and plants) with the Swine D1 strain. Hybridizations were also performed using a probe derived from a cell culture strain S743. Again, there was a large difference $\left(3\right.$ to $\left.6{ }^{\circ} \mathrm{C}\right)$ in the $t_{\mathrm{e}} 50$ values for heteroduplexes of strains isolated from diverse sources. The hybridization values of these diverse strains from different origins ranged from 52.5 to $70.1 \%$ homology with the cell culture strain $\mathrm{S} 743$ probe. The considerable genotypic heterogeneity among $A$. axanthum strains was also reflected by marked differences in the electrophoretic patterns of the digestion products of their DNAs by restriction endonucleases (Razin et al., 1983). It is tempting to suggest that the amount of homology or relatedness among strains may be influenced by the residing host.

Probes prepared to the PG-9, L and MIST strains of $A$. laidlawii showed results similar to that observed with $A$. axanthum strains. DNA probes of the PG-9, L and MIST strains of $A$. laidlawii hybridized $82.3,91.9$, and $82.0 \%$ to their homologous DNA. The amount of homology with these three probes (PG-9, L and MIST) and the other 11 heterologous DNA ranged from 62.9 to $92.9 \%$. The $t_{\mathrm{e}} 50$ values ranged accordingly and varied from $77.6{ }^{\circ} \mathrm{C}$ for ${ }^{3} \mathrm{H}-\mathrm{MIST}$ and PG-5 to $83.5{ }^{\circ} \mathrm{C}$ for the ${ }^{3} \mathrm{H}-\mathrm{L}$ strain and MIST indicating 8.5 and $0.9 \%$ mismatching of base pairing for the heteroduplexes, respectively. Reciprocal hybridizations using the MIST probe confirmed the high level of nucleotide homology between the L and MIST strains ( $\geqslant 90 \%)$. The $t_{\mathrm{e}} 50$ values for these heteroduplexes were only 0.6 to $0.8^{\circ} \mathrm{C}$ lower than the homoduplexes indicating less than $1.2 \%$ mismatching in base pairing. The results obtained for the $A$. laidlawii strains also suggest that the amount of relatedness or homology may be influenced by the host from which the strain was isolated.

Although the basis for the large variation among these strains of A. laidlawii and A. axanthum is unknown, these strains were recovered from diverse host and habitats. Whether the host or habitat influences the genotypic expression of the organisms remains to be determined. Such studies are under investigation. Nonetheless, five strains of $M$. pneumoniae isolated from different patients (but only one host) with primary atypical pneumonia showed from 85 to $100 \%$ homology. These data indicate that strains of $M$. pneumoniae are very similar and that the species $M$. pneumoniae is remarkably homogeneous (Chandler $e t$ al., 1982).

This and earlier studies (Aulakh et al., 1979, 1983; Stephens et al., 1981) show that the homology among strains of a given Acholeplasma species is approximately $50 \%$ or more, showing no more than $12 \%$ mismatching in base pairing among the common sequences. In addition, the prototype strains representing eight different Acholeplasma species show less than $25 \%$ homology and more than $12 \%$ mismatching of base pairing. These data may provide useful information to be used in guidelines to define properties required to establish a new species of Acholeplasma.

\section{REFERENCES}

AulakH, G. S. \& Gallo, R. C. (1977). Rauscherleukemia virus related sequence in human DNA: presence in some tissue of patients with hematopoietic neoplasma and absence in DNA from other tissues. Proceedings of the National Academy of Sciences of the United States of America 74, $353-357$

Aulakh, G. S., Tully, J. G. \& Barile, M. F. (1979). Differentiation among some acholeplasmas by nucleic acid homology. Current Microbiology 2, 71-94.

Aulakh, G. S., Stephens, E. B., Rose, D. L., Tully, J. G. \& BARILE, M. F. (1983). Nucleic acid relationships among Acholeplasma species. Journal of Bacteriology 153, 1338-1341

BARILE, M. F. (1979). Mycoplasma-tissue cell interactions. In The Mycoplasmas, vol. 2, Human and Animal Mycoplasmas, pp. 425-474. Edited by J. G. Tully \& A. F. Whitcomb. New York: Academic Press.

Britten, R. J., Povich, M. \& Smith, J. (1968). A new method for DNA purification. Annual Report of the Carnegie Institution, Washington, D.C., pp. 400-403.

Britten, R. J., Graham, D. E. \& Neufeld, D. (1974). Analysis of repeating DNA sequences by reassociation. Methods in Enzymology 29, 363-419.

Chandler, D. K. F., Razin, S., Stephens, E. B., Harasawa, R. \& Barile, M. F. (1982). Genomic and phenotypic analyses of Mycoplasma pneumoniae strains. Infection and Immunity 38, 604-609.

ClYDE, W. A., JR (1964). Mycoplasma species identification based upon growth inhibition by specific antisera. Journal of Immunology 92, 958-965.

Daniels, M. J. \& Meddins, B. M. (1972). Studies of plant mycoplasmas. 63rd Annual Report, John Innes Institute, Norn'ich, England, pp. 101-102.

DelGiudice, R. A., Robillard, N. F. \& Carski, T. R (1967). Immunofluorescence identification of mycoplasma on agar by use of incident illumination. Journal of Bacteriology 93, 1205-1209.

EDEN-GreEN, S. J. (1977). Attempts to extract and 
culture mycoplasmas from coconut palms. Proceedings of the Third Meeting of the International Council in Lethal Yellowing, p. 29. University of Florida Publication FL-78-2.

EDEN-GrEEN, S. J. (1978). Isolation of acholeplasmas from coconuts affected by lethal yellowing disease in Jamaica. Zentralblatt für Bakteriologie, Parasitenkunde, Infektionskrankheiten und Hygiene (Abteilung I, Originale A) 241, 226.

Eden-Green, S. J. \& Tully, J. G. (1979). Isolation of Acholeplasma sp. from coconut palms affected by lethal yellowing disease in Jamaica. Current Microbiology 2, 311-316.

Kelly, R. B., Cozzrelli, N. R., Deutschen, M. P., LEHMAN, I. R. \& KoRNBERG, A. (1970). Enzymatic synthesis of deoxyribonucleic acids. Journal of Biological Chemistry 245, 39-45.

Kleinhempel, M., Muller, H. M. \& SpaAR, D. (1972). Isolierung und Kultiverung von Mycoplasmatales aus Weissklee mit Blütenvergrünungssymptomen. Archiv fur Pflanzenschutz 8, 361-370.

Laird, C. E., McConaughly, B. L. \& McCarthy, B. J. (1969). Rate of fixation of nucleotide substitutions in evolution. Nature, London 224, 149-154.

Maniatis, T., Jeffrey, A. \& Kleid, D. G. (1975). Nucleotide sequence of the rightward operator of phage. Proceedings of the National Academy of Sciences of the United States of America 72, 11841188.

McCoy, R. E., Basham, M. G., Tully, J. G. \& Rose, D. (1980). Isolation of a new acholeplasma from flowers in Florida. Abstracts of the Third Conference of the International Organization for Mycoplasmology, p. 88 .

Orning, A. P., Ross, R. F. \& Barile, M. F. (1978). Isolation of Mycoplasma arginini from swine and from a swine waste disposal system. American Journal of Veterinary Research 39, 1169-1174.

Razin, S., Tully, J. G., Rose, D. L. \& Barile, M. F. (1983). DNA cleavage patterns as indicators of clonality and genotypic heterogeneity among strains of Acholeplasma and Mycoplasma species. Journal of General Microbiology 129, 1935-1944.
Rose, D. L., Tully, J. G. \& DelGiudice, D. A. (1980). Acholeplasma morum, a new non-sterolrequiring species. International Journal of Systematic Microbiology 30, 647-654.

Somerson, N. L., KockA, J. P., Rose, D. \& DelGiudice, D. A. (1982). Isolation of acholeplasmas and a mycoplasma from vegetables. Applied Environmental Microbiology 43, 412-417.

SEIFFERT, G. (1937). Uber das Vorkommen filtrabler Mikroorganismen in der Natur und ihre Zuchtbarkeit. Zentralblatt für Bakteriologie, Parasitenkunde, Infektionskrankheiten und Hygiene (Abteilung I, Originale A) 140, 337-342.

Stephens, E. B., Aulakh, G. S., McCoy, R. E., Rose, D. L., Tully, J. G. \& Barile, M. F. (1981). Lack of genetic relatedness among some animal and plant acholeplasmas by nucleic acid hybridization. Current Microbiology 5, 367-370.

SubCommitTeE ON THE TAXONOMY OF Mollicutes, International Committee on Systematic Bacteriology. (1979). Proposal of minimal standards for description of new species of the class Mollicutes. International Journal of Systematic Bacteriology 29, 172-180.

Tully, J. G. (1973). Biological and serological characteristics of the acholeplasmas. Annals of New York Academy of Sciences 225, 74-93.

Tully, J. G. (1979). Special features of the acholeplasmas. In The Mycoplasmas, vol. 1, Cell Biology, pp. 431-449. Edited by M. F. Barile \& S. Razin. New York: Academic Press.

Tully, J. G. \& RaZin, S. (1968). Physiological and serological comparisons among strains of $\mathrm{Myco}$ plasma granularum, and Mycoplasma laidlawii. Journal of Bacteriology 95, 1504-1512.

Tully, J. G. \& RaZIN, S. (1969). Characteristics of a new sterol-nonrequiring Mycoplasma. Journal of Bacteriology 98, 970-978.

Whitcomb, R. F., Tully, J. G., Rose, D. L., Stephens, E. B., Barile, M. F., Smith, A. \& McCoy, R. E. (1982). Wall-less prokaryotes from fall flowers in central United States and Maryland. Current Microbiology 7, 279-284. 